\title{
Inheritance of spot blotch resistance in barley (Hordeum vulgare L.)
}

\author{
Sarvjeet Singh¹, Harvinder Singh ${ }^{1}$, Achla Sharma ${ }^{1}$, Madhu Meeta ${ }^{1}$, Baljit Singh ${ }^{1}$, \\ Neha Joshi ${ }^{1}$, Pooja Grover ${ }^{1}$, Adnan Al-Yassin ${ }^{2}$, and Shiv Kumar ${ }^{2}$ \\ ${ }^{1}$ Department of Plant Breeding \& Genetics, Punjab Agricultural University, Ludhiana 141 004, India; and \\ ${ }^{2}$ Biodiversity and Integrated Gene Management Program, (BIGMP), International Center for Agricultural \\ Research in the Dry Areas (ICARDA), P.O. Box 5466, Aleppo, Syria. \\ Received 11 May 2013, accepted 28 March 2014. Published on the web 15 April 2014.
}

\begin{abstract}
Singh, S., Singh, H., Sharma, A., Meeta, M., Singh, B., Joshi, N., Grover, P., Al-Yassin, A. and Kumar, S. 2014. Inheritance of spot blotch resistance in barley (Hordeum vulgare L.). Can. J. Plant Sci. 94: 1203-1209. Spot blotch, caused by Bipolaris sorokiniana, is a major disease of barley hampering its commercial production in many parts of the world Growing resistant cultivars is the most effective, economical and eco-friendly approach to control the disease. To understand the inheritance of resistance, $F_{1}, F_{2}$ and $F_{3}$ generations of two crosses, involving susceptible (PL426 and RD2503) and resistant (BL9 and BL10) parents were studied. The susceptibility of $F_{1}$ plants and a ratio of 13 susceptible:3 resistant in $\mathrm{F}_{2}$ populations in both crosses indicated that the reaction to spot blotch is hypostatic and is governed by two genes with an epistatic/inhibitory effect of first on the second one. The resistant reaction appeared due to the presence of dominant allele of the second gene. The first gene in dominant homozygous or heterozygous condition had an inhibitory effect over the second gene. The inheritance pattern was confirmed from the segregation pattern of $\mathrm{F}_{3}$ progenies of both the crosses. One hundred-fifty $\mathrm{F}_{2: 6}$ recombinant inbred lines (RIL) derived from PL426/BL10 cross gave a good fit to the ratio of 1 resistant:3 susceptible lines under artificial and natural epiphytotic conditions. Recovery of transgressive segregants in the RIL population indicated the presence of some modifiers or minor genes. Test of allelism involving susceptible $($ PL426) $\times$ susceptible $($ RD2503) and resistant (BL9) $\times$ resistant $($ BL10) parents revealed that both the susceptible parents as well as resistant parents were allelic to each other.
\end{abstract}

Key words: Barely, Hordeum vulgare, spot blotch, inheritance

Singh, S., Singh, H., Sharma, A., Meeta, M., Singh, B., Joshi, N., Grover, P., Al-Yassin, A. et Kumar, S. 2014. Hérédité de la résistance à la tache helminthosporienne chez l'orge (Hordeum vulgare L.). Can. J. Plant Sci. 94: 1203-1209. Maladie importante de l'orge, la tache helminthosporienne causée par Bipolaris sorokiniana nuit à la production commerciale de cette céréale dans maintes régions du globe. La façon la plus efficace, la moins onéreuse et la plus écologique de lutter contre elle consiste à cultiver des variétés résistantes. Pour mieux comprendre l'hérédité de la résistance, les auteurs ont étudié la, $F_{1}$, la $F_{2}$ et la $F_{3}$ de deux croisements entre des parents sensibles (PL426 et RD2503) et résistants (BL9 et BL10). La sensibilité des plants de la $F_{1}$ et le rapport de 13 plants sensibles pour 3 résistants dans la $F_{2}$ pour les deux croisements révèlent que la réaction à la tache helminthosporienne est hypostatique et régie par deux gènes, le premier ayant un effet épistatique/inhibiteur sur le second. La résistance survient quand l'allèle dominant se trouve sur le second gène. Chez les homozygotes et les hétérozygotes, le premier gène domine le second. L’hérédité de la résistance a été confirmée par le schéma de ségrégation de la $\mathrm{F}_{3}$, c'est-à-dire la progéniture des deux croisements. Cent cinquante lignées autogames recombinantes (LAR) de la $\mathrm{F}_{2: 6}$ issues du croisement PL426/BL10 étaient bien ajustées au ratio 1 lignée résistante pour 3 sensibles dans des conditions artificielles et naturelles d'épiphytie. La découverte de ségrégants transgressifs dans la population de LAR laisse supposer la présence de quelques gènes mineurs ou modificateurs. Les essais d'allélisme avec des parents sensibles $($ PL426) $\times$ sensibles $($ RD2503) et résistants $($ BL9) $\times$ résistants $($ BL10) révèlent que les deux parents sensibles de même que les parents résistants sont mutuellement alléliques.

Mots clés: Orge, Hordeum vulgare, tache helminthosporienne, hérédité

Barley (Hordeum vulgare L.) is an important crop and ranks fourth among the major food grain crops in the world. It has a special significance in dryland Agriculture due to its ability to withstand severe drought in addition to low input requirements for its successful cultivation. Barley is considered the best choice of crop for saline-alkaline soils under rainfed conditions (Singh and Singh 1991). However, the crop suffers significant yield losses from biotic stresses. Among biotic stresses, spot blotch caused by Bipolaris sorokiniana (Sacc. in Sorok.) Shoemaker, syn. Helminthosporium sativus, telomorph Cochliobolus sativus (Ito and Kuribayashi.) Dreschsl. ex Dastur. is a serious fungal disease with a wide geographical distribution. It is a major disease in warmer and humid growing regions of the world (Kuldeep et al. 2008).

Abbreviations: PAU, Punjab Agricultural University; RIL, recombinant inbred lines 
This disease can cause 10 to $100 \%$ yield losses in susceptible cultivars besides causing deterioration of grain quality (Clark 1979; van Leur 1991; Mathre 1997).

The spot blotch frequently hampers commercial production of barley in the northeastern region of India, and it has gained significance in northwestern states as well (Bala and Kaur 2008). The changing agronomic practices in barley cultivation and the rapid replacement of locally adapted varieties with high-yielding cultivars have led to emergence of this disease, which was hitherto insignificant in the irrigated areas of the northwestern plains of India. It is believed that $B$. sorokiniana might be perpetuating on rice stubble to cause infection in the barley crop as the environmental conditions remain congenial for the survival and development of the pathogen throughout the year (Karwasra et al. 1998). Different control measures are adopted to manage spot blotch in barley. Foliar fungicides can be used to maintain yield and quality; however, producers incur additional cost and fungicides may have adverse environmental effects. Thus, growing resistant cultivars is the most effective, economical and eco-friendly approach to control the disease. Understanding the inheritance of resistance to disease is valuable for planning crosses in breeding programs, identifying resistance genes and developing genetic markers to assist in selection.

The genetic information on spot blotch resistance in barley is scarce, especially in the Indian germplasm. Barley genotypes with higher levels of resistance are difficult to achieve owing to the quantitative nature of resistance and influence of environment on disease development (Wilcoxson et al. 1990; Bailey and Wolf 1994; Kutcher et al. 1994). Hence, comprehensive and clear information with respect to inheritance of spot blotch resistance is required to design suitable breeding strategies to enhance resistance of high yielding barley cultivars. The objective of this research was to study the inheritance of spot blotch resistance.

\section{MATERIALS AND METHODS}

\section{Plant Material}

Four barley genotypes viz., PL426 (Karan92/PL101), RD2503 (RD103/BH153), BL9 (LENT/BLLU//PINON) and BL10 (BOLDO/MJA//PINON) were used in the present study. PL426 and RD2503 are susceptible to spot blotch disease and are still widely grown in different agroclimatic regions in India, while BL9 and BL10 are the advanced breeding lines from ICARDA (International Centre for Agricultural Research in the Dry Areas, Syria) with high spot blotch resistance but poor adaptation to the Indian conditions. Four crosses namely, PL426/ $\operatorname{BL} 10\left(\mathrm{C}_{1}\right), \mathrm{RD} 2503 / \mathrm{BL} 9\left(\mathrm{C}_{2}\right), \mathrm{PL} 426 / \mathrm{RD} 2503\left(\mathrm{C}_{3}\right)$, and BL10/BL9 $\left(\mathrm{C}_{4}\right)$, were attempted at Punjab Agricultural University (PAU), Ludhiana, India (lat. $30^{\circ} 54^{\prime} \mathrm{N}$, long. $75^{\circ} 48^{\prime} \mathrm{E}$ ) during the winter season of 2005-2006. The experimental soil was loamy sand (light textured) with $2.9 \%$ organic carbon content with a $\mathrm{pH}$ of $7.8-8.0$.
The experimental fields were low in available nitrogen (85-132 $\mathrm{kg} \mathrm{ha}^{-1}$ ) and phosphorus (15-19 $\mathrm{kg} \mathrm{ha}^{-1}$ ) and medium high in potassium (245-310 $\left.\mathrm{kg} \mathrm{ha}^{-1}\right)$ content. The climate is cool during nights from mid-November to mid-February. The days are sunny with high humidity (max. RH $>90 \%$ ) during November to February and warm sunny during March-April. The average rainfall during the crop growth period (November to mid-April) is $\sim 172 \mathrm{~mm}$. The $\mathrm{F}_{1} \mathrm{~s}$ were grown in the following season (2006-2007) to harvest $F_{2}$ seed and subsequent $F_{2}$ generation during 2007-2008. In addition, the $\mathrm{F}_{3}$ generation was derived only from two crosses; $\mathrm{C}_{1}$ and $\mathrm{C}_{2}$. All plants (244 in $\mathrm{C}_{1}$ and 186 in $\mathrm{C}_{2}$ ) of $\mathrm{F}_{2}$ populations formed the $\mathrm{F}_{3}$ plant progenies. These $\mathrm{F}_{3}$ single plant progenies were evaluated to confirm the pattern of inheritance observed in the $\mathrm{F}_{2}$ generation. A recombinant inbred lines (RIL) population (164 $\mathrm{F}_{6}$ lines) was developed from $\mathrm{C}_{1}$ cross using the single seed descent (SSD) method through rapid generation advancement of $\mathrm{F}_{2: 6}$ generations in the main season (November to April) and off-season (May to September). The PAU Off-season Research Station is located at Keylong, Lahaul Spiti, Himachal Pradesh, India (lat. $32.57^{\circ} \mathrm{N}$, long. $77.03^{\circ} \mathrm{E}, \sim 3300 \mathrm{~m}$ asl).

\section{Disease Screening}

This study was carried out at the Experimental Area of Wheat Section, Department of Plant Breeding and Genetics, Punjab Agricultural University, Ludhiana, India, which is a hot-spot for the spot blotch disease and at the PAU Off-season Research Station, Keylong. The $F_{1}$ and $F_{2}$ generations of the four crosses $\left(C_{1}\right.$ to $\left.C_{4}\right)$ along with their respective parents were screened against spot blotch in the field under natural epiphytotic conditions during the winter season of 2007-2008, whereas $\mathrm{F}_{3}$ generations of two crosses $\left(\mathrm{C}_{1}\right.$ and $\left.\mathrm{C}_{2}\right)$ were screened during the winter season of 2008-2009. The plot size varied with generations. Parents, $F_{1}$ and single plant progenies in $\mathrm{F}_{3}$ generation were grown in two-row plots and $F_{2}$ generation in as many rows as possible depending on the quantity of seeds available in various crosses. The RIL population of $\mathrm{C}_{1}$, comprising $150 \mathrm{~F}_{2: 6}$ lines, was planted in the field under natural epiphytotic conditions during the winter season of 2010-2011 in a Randomized Complete Block Design using three replicates. Each replicate included two rows of $2 \mathrm{~m}$ length of each RIL, with spacings of $23 \mathrm{~cm}$ between rows and $10 \mathrm{~cm}$ between plants within row. In addition, $14 \mathrm{~F}_{2: 6}$ lines of the same RIL population were planted in a single row for screening against spot blotch due to limited seed availability. The infector rows (mixture of susceptible lines) were grown around the experiment as well as after every 20th row of testing materials $\left(\mathrm{F}_{2}, \mathrm{~F}_{3}\right.$ and RILs) for the inoculum development and spread. The RIL population of $\mathrm{C}_{1}$, along with parents, was planted in a glasshouse for artificial screening during winter season in 2010-2011. Planting of all the experiments took place in mid-November in the above-mentioned years. 
The isolate BS2 of B. sorokiniana was procured from Directorate of Wheat Research (DWR), Karnal, India. It is the most virulent and prevalent isolate in the barleygrowing areas of northern India, and was used for artificial screening in the present study. Initially, the culture of isolate was prepared on sorghum seeds and then grown on potato dextrose agar with $\mathrm{pH} 6.5$ and kept in an incubator for $5 \mathrm{~d}$ at $25 \pm 1^{\circ} \mathrm{C}$. Sorghum seeds $(50 \mathrm{~g})$ were soaked overnight and placed in a $250-\mathrm{mL}$ flask. The material was sterilized in an autoclave at $15 \mathrm{lb}$ pressure for $40 \mathrm{~min}$. The sorghum seeds were then inoculated (under aseptic conditions) with culture growing on potato dextrose agar. The flask contents were periodically shaken to enhance the intensity of sporulating inoculum. The flasks were kept at $25^{\circ} \mathrm{C}$. Then, after 6-8 wk water was added in flasks and spore concentration was adjusted to $1 \times 10^{6}$ spores $\mathrm{mL}^{-1}$. A few drops of Tween-20 (surfactant) were also added and then inoculum was sprayed on the plant material and inoculated sorghum granules were broadcasted. The sprays were generally performed in the afternoon and were repeated weekly to cover all new foliage. The first inoculation on the barley crop was performed at maximum tillering stage and continued until flowering (first week of March) to maintain high inoculum pressure. The field was irrigated frequently to ensure high humidity for disease development.

\section{Disease Evaluation}

The severity of disease was recorded on each plant/ progeny using the double digit scale (00-99) proposed by Nagarajan (1998) by visually scoring the percent diseased area on the flag (first digit) and penultimate (second digit) leaves. The plants/progenies were categorized as Immune (00 score), resistant (01-14 score, lesions absent or small without chlorosis), moderately resistant (15-35 score, lesions small but with some chlorosis), moderately susceptible (36-55 score, lesions large with extensive chlorosis but little or no coalescence), susceptible (56-79 score, lesions large and coalescence with chlorosis) and highly susceptible ( $>79$ score, lesions large and extensive coalescence with severe chlorosis) based on disease reaction. The $\mathrm{F}_{2}$ plants were classified into two classes, viz., (i) resistant; consisting of resistant and moderately resistant plants and (ii) susceptible; consisting of moderately susceptible, susceptible and highly susceptible plants. Similarly, the $\mathrm{F}_{3}$ families were classified into three classes viz., (i) resistant, consisting of resistant and moderately resistant progenies; (ii) segregating; and (iii) susceptible, consisting of moderately susceptible, susceptible and highly susceptible progenies. The segregating class included a mixture of all the classes viz., resistant, moderately resistant, moderately susceptible, susceptible and highly susceptible plants. The RIL population was also classified into two classes viz., resistant and susceptible. Hypothetical gene symbols $(R I$ and $R 2)$ were used to explain the genetics of inheritance.

\section{Yield Evaluation}

Data for grain yield per plot (two rows of $2 \mathrm{~m}$ length spaced at $23 \mathrm{~cm}=0.92 \mathrm{~m}^{2}$ ) of RILs were recorded from all the three replications from the same experiment, which was planted for disease screening and converted to kilograms per hectare.

\section{Statistical Analysis}

A chi-square $\left(\chi^{2}\right)$ test with Yates correction (Panse and Sukhatme 2000) was applied to test the goodness of fit of the expected segregation in $F_{2}, F_{3}$ and $F_{6}$ generations. The significance of $\chi^{2}$ value was tested against tabulated value of $\chi^{2}$ at $n-1$ degree of freedom. Data recorded for grain yield of RILs were subjected to Analysis Of Variance (ANOVA).

\section{Inheritance of Resistance}

The spot blotch reaction of parents, $F_{1}$ and $F_{2}$ and grouping of plants into resistant and susceptible categories are given in Fig. 1a-d. All the plants of parents PL426 and RD2503 showed susceptibility (average score 67), whereas all plants of parents BL9 and BL10 were resistant (average score 22). All $\mathrm{F}_{1}$ plants from the two crosses, $\mathrm{C}_{1}$-PL426/BL10 $(\mathrm{S} \times \mathrm{R})$ and $\mathrm{C}_{2}$-RD2503/BL9 $(\mathrm{S} \times \mathrm{R})$, were susceptible (score 57-67). The $\mathrm{F}_{2}$ populations of $C_{1}$ and $C_{2}$ were segregated into susceptible and resistant plants. Out of $262 \mathrm{~F}_{2}$ plants of $\mathrm{C}_{1}, 222$ plants were susceptible and 40 plants were resistant and gave a good fit to the ratio of 13:3 $\left(\chi^{2}=1.863\right.$, Table 1$)$. Similarly, out of $203 \mathrm{~F}_{2}$ plants of $\mathrm{C}_{2}, 170$ plants were susceptible and 33 plants were resistant, and these also fit well to the proposed ratio of 13:3 ratio $\left(\chi^{2}=0.828\right)$.

The inheritance pattern was confirmed from the segregation pattern of $\mathrm{F}_{3}$ progenies of $\mathrm{C}_{1}$ and $\mathrm{C}_{2}$ (data not shown). Out of $244 \mathrm{~F}_{3}$ progenies of $\mathrm{C}_{1}$ cross, 98 were susceptible, 134 segregating and 12 resistant, giving a good fit to the expected ratio of 7 susceptible: 8 segregating: 1 resistant. These $134 \mathrm{~F}_{3}$ segregating progenies were derivatives of 24 resistant and 110 susceptible $F_{2}$ plants (Table 2). Forty $F_{2}$ plant-derived $F_{3}$ progenies $\left(F_{2: 3}\right)$ (having sufficient plants) from 10 resistant and 30 susceptible plants were selected to record observation on segregation pattern to further confirm the inheritance pattern. Among the $10 \mathrm{~F}_{2}$-resistant plant derived progenies, four did not segregate, while six segregated into 3:1 (resistant: susceptible) ratio. Similarly, out of 30 progenies derived from $\mathrm{F}_{2}$-susceptible plants, 10 segregated into 13:3 (susceptible: resistant) ratio, four progenies into 3:1 (susceptible: resistant) ratio, and the remaining 16 progenies were susceptible.

The $\mathrm{F}_{3}$ progenies of $\mathrm{C}_{2}$ also gave a good fit to the ratio of 7: 8: 1, when 79, 107 and 10 progenies were found susceptible, segregating and resistant, respectively (Table 1). Out of 107 segregating progenies in $\mathrm{F}_{3}$ generation, 20 were from $F_{2}$ resistant plants and 87 from $F_{2}$ susceptible plants (Table 2). From those, $36 \mathrm{~F}_{3}$ progenies with 
a)

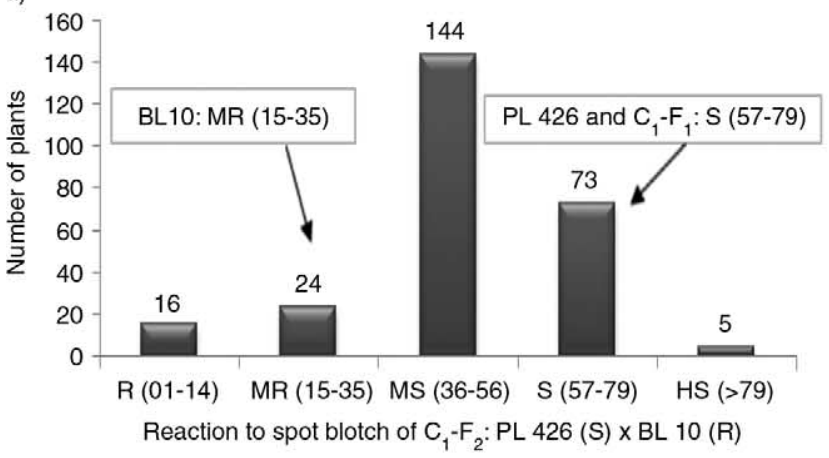

c)

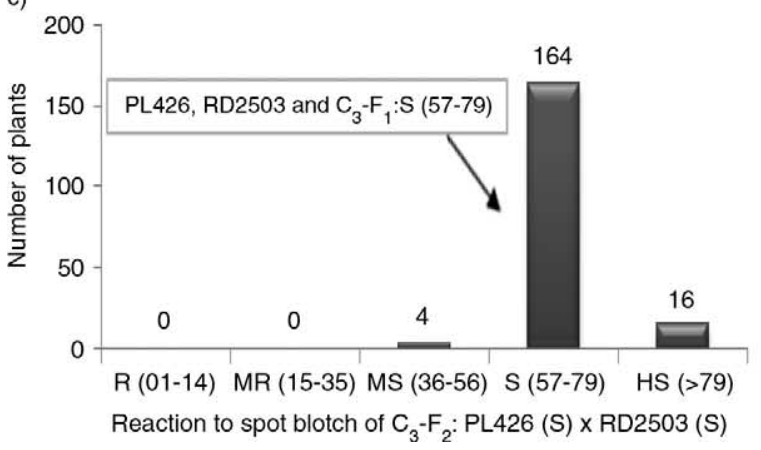

b)

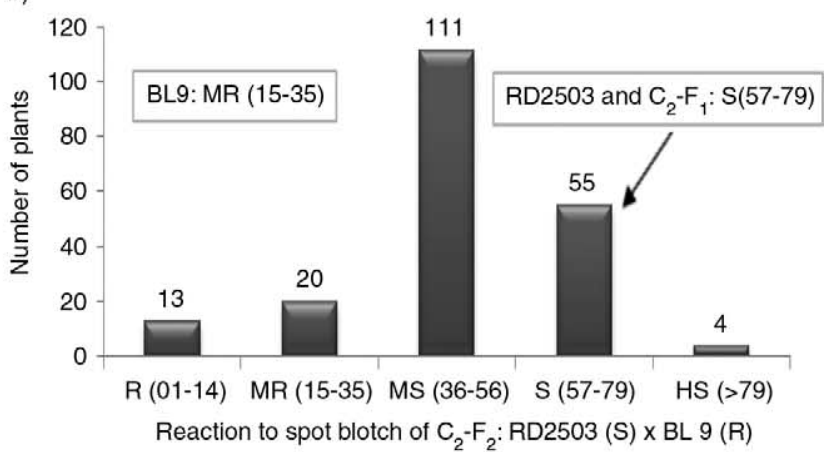

d)

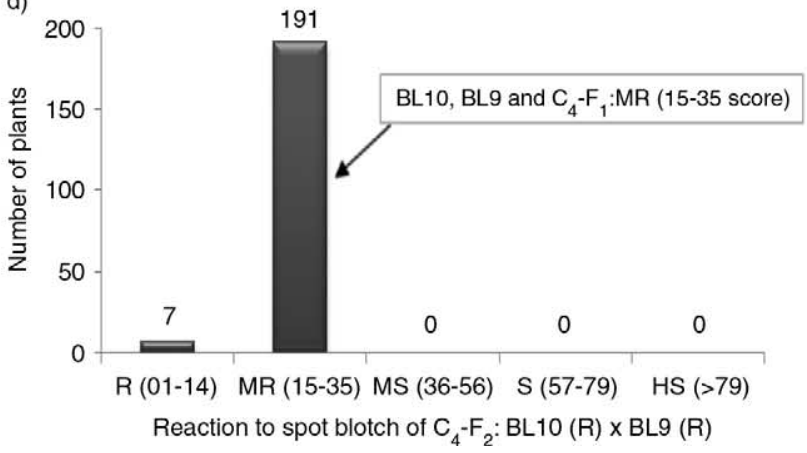

Fig. 1. Reaction of parents, $F_{1}$ and $F_{2}$ to spot blotch of four crosses, $C_{1}$ : PL426 (S)/BL10 (R) (Fig. 1a); C 2 : RD2503 (S)/BL9 (R) (Fig. 1b); C 3 : PL426 (S)/RD2503 (S) (Fig. 1c); C 4 : BL10 (R)/BL9 (R) (Fig. 1d).

sufficient plants representing 9 resistant and 27 susceptible $F_{2}$ plants, individual plant reaction was recorded for confirmation of the inheritance pattern. From the 9 resistant $\mathrm{F}_{2: 3}$ derived progenies, there were three nonsegregating progenies, and six segregated in a $3: 1$ (resistant: susceptible) ratio. The remaining 27 susceptible $\mathrm{F}_{2: 3}$ progenies showed that 10 progenies were segregated in 13 susceptible: 3 resistant ratio, four segregated in 3 susceptible: 1 resistant ratio, and 13 progenies were susceptible.

The reaction of 150 RILs to spot blotch under artificial epiphytotic conditions showed that there were 35 resistant and 115 susceptible lines (Table 1). Similar results were observed under natural epiphytotic field conditions, when 164 RILs segregated as 32 resistant and 132 as susceptible (Table 1). These segregation patterns under natural as well as artificial conditions gave a good fit to the ratio of 1:3 (resistant: susceptible). In this study, the average score of resistant parents was 22 and the susceptible parents was 67 . However, transgressive segregants were observed with either higher degree of resistance $(<22$ score) or higher degree of susceptibility ( $>67$ score).

\section{Test of Allelism}

All $F_{1}$ and $F_{2}$ plants from $C_{3}$ cross (PL426/RD2503; $\mathrm{S} \times \mathrm{S}$ ) were susceptible, while all $\mathrm{F}_{1}$ and $\mathrm{F}_{2}$ plants from $\mathrm{C}_{4}$ cross (BL10/BL9; $\mathrm{R} \times \mathrm{R}$ ) were resistant (Fig. 1c-d).
Thus, the susceptible parents (PL426 and RD2503) and resistant parents (BL9 and BL10) were allelic to each other with respect to susceptibility or resistance to spot blotch. Yet, higher degrees of susceptibility (in $\mathrm{C}_{3}$ ) or resistance (in $\mathrm{C}_{4}$ ) were observed in the $\mathrm{F}_{2}$ populations.

\section{Consistency of RILs for Disease Reaction Under Natural and Artificial Conditions}

The RILs were compared for consistency in their reaction to spot blotch under natural and artificial conditions. Of the 150 RILs tested under both conditions, $131(87.33 \%)$ showed consistency in their reaction to spot blotch, as 11 lines showed resistant, 19 moderately resistant, 30 moderately susceptible, 70 susceptible and one highly susceptible reaction under both natural and artificial conditions. However, some lines were not consistent in their reaction to spot blotch, as two moderately resistant lines under natural conditions showed moderately susceptible reaction under artificial conditions. Similarly, five moderately resistant lines under artificial conditions showed susceptible reaction under natural conditions. Three moderately susceptible lines under natural conditions showed susceptible reaction under artificial conditions. Five moderately susceptible and four susceptible lines under artificial conditions showed, respectively, susceptible and highly susceptible reaction under natural conditions. 


\begin{tabular}{|c|c|c|c|c|c|c|c|}
\hline Generation & $\begin{array}{l}\text { Total plants/ } \\
\text { progenies }\end{array}$ & $\begin{array}{c}\text { Susceptible } \\
\text { plants/progenies }\end{array}$ & $\begin{array}{l}\text { Segregating } \\
\text { progenies }\end{array}$ & $\begin{array}{l}\text { Resistant plants/ } \\
\text { progenies }\end{array}$ & $\begin{array}{l}\text { Expected ratio } \\
\text { S:Seg: } R^{\mathbf{Z}}\end{array}$ & $\Sigma \chi^{2}$ & Probability \\
\hline \multicolumn{8}{|l|}{$\mathrm{C}_{1}:$ PL426/BL10 } \\
\hline $\mathrm{F}_{1}$ & 8 & 8 & 0 & 0 & - & - & - \\
\hline $\mathrm{F}_{2}$ & 262 & 222 & 0 & 40 & $13: 0: 3$ & 1.863 & 0.1722 \\
\hline $\mathrm{F}_{3}$ & 244 & 98 & $134^{y}$ & 12 & 7:8:1 & 2.217 & 0.3300 \\
\hline $\begin{array}{l}\text { RILs }\left(\mathrm{F}_{6}\right) \text { Artificial epiphytotic } \\
\text { condition }\end{array}$ & 150 & 115 & 0 & 35 & $3: 0: 1$ & 0.178 & 0.6730 \\
\hline $\begin{array}{l}\text { RILs }\left(F_{6}\right) \text { Natural epiphytotic } \\
\text { field condition }\end{array}$ & 164 & 132 & 0 & 32 & 3:0:1 & 2.349 & 0.1253 \\
\hline \multicolumn{8}{|l|}{$\mathrm{C}_{2}: \mathrm{RD} 2503 / \mathrm{BL} 9$} \\
\hline$F_{1}$ & 7 & 7 & 0 & 0 & - & - & - \\
\hline$F_{2}$ & 203 & 170 & 0 & 33 & $13: 0: 3$ & 0.828 & 0.3628 \\
\hline $\mathrm{F}_{3}$ & 196 & 79 & $107^{x}$ & 10 & $7: 8: 1$ & 1.442 & 0.4862 \\
\hline
\end{tabular}

${ }^{\mathrm{z}} \mathrm{S}$, susceptible; R, resistant; Seg, segregating.

${ }^{\mathbf{y}}$ Derived from 24 resistant and 110 susceptible $\mathrm{F}_{2}$ plants.

${ }^{\mathrm{x}}$ Derived from 20 resistant and 87 susceptible $\mathrm{F}_{2}$ plants.

The yield performance of some resistant and moderately resistant lines is given in Table 3 . The highestyielding moderately resistant line $\mathrm{BF}_{6}-84\left(6409 \mathrm{~kg} \mathrm{ha}^{-1}\right)$, recorded $41.85 \%$ superiority over the best check BL10 $\left(4518 \mathrm{~kg} \mathrm{ha}^{-1}\right)$, followed by resistant line $\mathrm{BF}_{6}-92(5536$ $\mathrm{kg} \mathrm{ha}{ }^{-1}$ ) and moderately resistant line $\mathrm{BF}_{6}-53$ (5272 $\mathrm{kg} \mathrm{ha}^{-1}$ ).

\section{DISCUSSION}

Spot blotch is a foliar disease causing loss of grain quality, which significantly affects net return if barley is downgraded from malt to feed. Foliar fungicides can be used to maintain yield and quality, but producers incur additional cost and, moreover, fungicides have adverse environmental effects and are not an option for organic farming. One of the main objectives of the Indian barley breeding program is to develop high-yielding cultivars with resistance to spot blotch disease through the transfer of genes from resistant sources. Although, there are a few reports on genetics of resistance to spot blotch (Arny 1951; Wilcoxson et al. 1990; Steffenson et al. 1996; ValjavecGratian and Steffenson 1997; Arabi 2005), recent studies have shown quantitative inheritance also (Grewal et al.
2012). In the present study, we observed digenic inheritance with some modifiers for spot blotch resistance in barley based on our results in $F_{1}, F_{2}$ and $F_{3}$ generations of four crosses and RIL populations of one cross. All the $F_{1}$ plants derived from crosses of susceptible $\times$ resistant parents were susceptible, suggesting that resistance is recessive or hypostatic to susceptibility.

The $F_{2}$ populations of $C_{1}$ and $C_{2}$ crosses gave a good fit to the ratio of 13:3 suggesting that reaction to spot blotch was governed by two genes. Although quantitative inheritance was reported by Grewal et al. (2007, 2012), our results indicate digenic inheritance with epistatic or inhibitory effect of the first gene $(R I)$ on the second gene $(R 2)$. Grewal et al. (2012) reported that at the adult plant stage, the populations segregated for two to four genes at different locations. Our results suggest that the resistant reaction appeared due to the presence of dominant allele $(R 2)$ of the second gene and its recessive alleles $(r 2 r 2)$ determined susceptible reaction. The resistant reaction appeared only when the first gene was in homozygous recessive condition $(r \operatorname{lr} l)$. The first gene in dominant homozygous $(R I R l)$ or heterozygous $(R I r l)$ condition had inhibitory effect over the second gene and

\begin{tabular}{|c|c|c|c|c|}
\hline \multirow[b]{2}{*}{ Phenotype of $F_{3}$ progenies (reaction to spot blotch) } & \multicolumn{2}{|c|}{ No. of progenies } & \multirow{2}{*}{$\begin{array}{l}\text { Probable genotype of } F_{2} \\
\text { plants }\end{array}$} & \multirow[b]{2}{*}{ Expected ratio in $\mathrm{F}_{3}$} \\
\hline & $\mathrm{C}_{1}$ & $\mathrm{C}_{2}$ & & \\
\hline Total progenies derived from susceptible $F_{2}$ plants & 208 & 166 & & \\
\hline A. Susceptible non-segregating & 98 & 79 & $\begin{array}{c}R 1 R 1 R 2 ; R 1 \_r 2 r 2 ; \\
r 1 r 1 r 2 r 2\end{array}$ & All susceptible plants \\
\hline B. Total susceptible segregating & 110 & 87 & & \\
\hline B.1. Susceptible segregating & 75 & 63 & $R 1 r 1 R 2 r 2$ & $13 \mathrm{~S}: 3 \mathrm{R}$ \\
\hline B.2. Susceptible segregating & 35 & 24 & $R 1 r 1 R 2 R 2$ & $3 \mathrm{~S}: 1 \mathrm{R}$ \\
\hline Total progenies derived from resistant $F_{2}$ plants & 36 & 30 & & \\
\hline Resistant segregating & 24 & 20 & $r 1 r 1 R 2 r 2$ & $1 \mathrm{~S}: 3 \mathrm{R}$ \\
\hline Resistant non-segregating & 12 & 10 & $r 1 r 1 R 2 R 2$ & All resistant plants \\
\hline Total progenies & 244 & 196 & & \\
\hline
\end{tabular}




\begin{tabular}{|c|c|c|c|c|}
\hline \multirow[b]{2}{*}{ Sr. no. } & \multirow[b]{2}{*}{ RIL no. } & \multicolumn{2}{|c|}{ Spot blotch reaction (double digit score) } & \multirow[b]{2}{*}{ Yield $\left(\mathrm{kg} \mathrm{ha}^{-1}\right)$} \\
\hline & & Artificial conditions & Natural conditions & \\
\hline 1 & $\mathrm{BF}_{6}-5$ & $\mathrm{MR}^{\mathbf{z}}(35)$ & MR (34) & 4844 \\
\hline 2 & $\mathrm{BF}_{6}-53$ & MR (22) & MR (23) & 5272 \\
\hline 3 & $\mathrm{BF}_{6}-80$ & MR (25) & MR (23) & 4844 \\
\hline 4 & $\mathrm{BF}_{6}-84$ & MR (25) & MR (23) & 6409 \\
\hline 5 & $\mathrm{BF}_{6}-92$ & R (13) & R (12) & 5536 \\
\hline 6 & $\mathrm{BF}_{6}-110$ & R (12) & R (12) & 4663 \\
\hline 7 & $\mathrm{BF}_{6}-146$ & MR (23) & MR (23) & 4710 \\
\hline 8 & $\mathrm{BF}_{6}-153$ & MR (25) & MR (23) & 4797 \\
\hline 9 & $\mathrm{BF}_{6}-155$ & R (12) & R (12) & 5018 \\
\hline 10 & $\mathrm{BF}_{6}-183$ & R (11) & R (11) & 4717 \\
\hline 11 & PL $426\left(\mathrm{P}_{1}\right)$ & S (57) & S (67) & 4134 \\
\hline \multirow[t]{2}{*}{12} & BL $10\left(\mathrm{P}_{2}\right)$ & MR (25) & MR (22) & 4518 \\
\hline & $\mathrm{LSD}_{0.05}$ & - & - & 267 \\
\hline
\end{tabular}

${ }^{\mathrm{z}} \mathrm{R}$, Resistant; MR, moderately resistant; $\mathrm{S}$, susceptible.

suppressed the expression of resistant reaction and produced susceptible reaction.

Grewal et al. (2012) reported that a major seedling resistance QTL (QRcss 1$)$ on H1 explained $79 \%$ of the phenotypic variation for spot blotch resistance, and at adult-plant resistance to spot blotch, a highly significant QTL on $3 \mathrm{H}(Q R \operatorname{css} 3.2)$ explained $23 \%$ of the phenotypic variation. Although there are many QTLs consistently reported in one location or 1 year, there was one major QTL identified on $7 \mathrm{H}$ that contributed to seedling and adult-plant resistance in different barley populations. Other studies reported that the QTLs on 3HS and 7HS are consistently associated with spot blotch resistance (Bilgic et al. 2006; Bovill et al. 2010). The inheritance pattern was further confirmed from the segregation pattern of $\mathrm{F}_{2: 3}$ progenies as both crosses, $\mathrm{C}_{1}$ and $\mathrm{C}_{2}$, gave a good fit to the ratio of $7: 8: 1$ (susceptible: segregating: resistant). This indicates that reaction to spot blotch was under the control of two genes. The segregation pattern of RILs under natural epiphytotic field as well as under artificial conditions also gave a good fit to the ratio of one resistant: three susceptible. This provides the opportunity to obtain genetic gain through selection practices over segregating populations.

Inheritance of resistance to spot blotch disease has been reported to be governed by one, two, three or more genes (monogenic or polygenic inheritance) with different type of gene interactions, such as dominance or epistatic interaction or additive (Arny 1951; Wilcoxson et al. 1990; Steffenson et al. 1996; Valjavec-Gratian and Steffenson 1997; Grewal et al. 2007, 2012). Steffenson et al. (1996) observed that spot blotch resistance is governed by different genes at seedling and adult plant stages. At seeding stage spot blotch resistance is reported to be governed by a single gene that has been mapped to the distal region of chromosome $1 \mathrm{P}$, whereas two major QTL were identified for spot blotch resistance at adult plant stage on chromosomes 5P and 1P (Steffenson et al.
1996). Bilgic et al. (2006) also observed two different genetic systems conferring resistance at seedling and adult plant stages. Recently, Grewal et al. (2012) reported two-gene segregation for resistance to spot blotch isolates WRS1909 and SK1-1 in a doubled-haploid barley population and three-gene segregation for isolate WRS1908 at the seedling stage. At the adult-plant stage, the population segregated for two to four genes at different locations and in different years under field conditions. Recovery of many progenies with higher degree of resistance $(<22$ score) or higher degree of susceptibility ( $>67$ score) as compared with parents in the present study indicated the presence of some modifiers or minor genes.

The $F_{1}$ and $F_{2}$ plants from the cross between susceptible $\times$ susceptible parents were all susceptible, while on the other hand, the $F_{1}$ and $F_{2}$ plants derived from crosses between resistant $\times$ resistant parents were all resistant, which indicated that the susceptible parents PL426 and RD2503 and resistant parents BL9 and BL10 were allelic to each other with respect to susceptibility or resistance to spot blotch. However, the degree of susceptibility or resistance in respective crosses was higher in the $F_{2}$ populations, which suggested the presence of some modifiers or minor genes with positive or negative effects. The consistency for reaction to spot blotch under natural and artificial conditions of majority of the lines $(87.33 \%)$ indicated that environment was quite congenial for the spread and development of disease under both the conditions. All the 11 resistant and 19 moderately resistant $(73.07 \%)$ lines maintained their reaction indicated their stability for disease reaction. The inconsistency for disease reaction of some of the lines might be due to differences in the micro-environment surrounding those lines. The RIL population of cross PL426/BL10 will be used for mapping genes associated with spot blotch resistance. Some lines from this cross were recovered with a high degree of resistance to spot blotch and with high yield potential. These will be tested in multilocation trials 
to test their stability and adaptability. The well-adapted cultivar, PL426, which was also used as a susceptible parent, could not surpass the less-adapted resistant line BL10 due to a high incidence of spot blotch disease.

Arabi, M. I. E. 2005. Inheritance of partial resistance to spot blotch in barley. Plant Breed. 124: 605-607.

Arny, D. C. 1951. Inheritance of resistance to spot blotch in barley seedling. Phytopathology 41: 691-698.

Bailey, K. L. and Wolf, R. I. 1994. Genetic relationship between reaction to common root rot and yield in the progeny of a barley cross. Can. J. Plant Pathol. 16: 163-169.

Bala, A. and Kaur, S. 2008. Cross infectivity of Bipolaris sorokiniana among wheat, barley, triticale, rye and Phalaris minor. Plant Dis. Res. 23: 7-12.

Bilgic, H., Steffenson, B. J. and Hayes, P. M. 2006. Molecular mapping of loci conferring resistance to different pathotypes of the spot blotch pathogen in barley. Phytopathology 96: 699-708.

Bovill, J., Lehmensiek, A., Sutherland, M. W., Platz, G. J., Usher, T., Frackowiak, J. and Mace, E. 2010. Mapping spot blotch resistance genes in four barley populations. Mol. Breed. 26: 653-666.

Clark, R. V. 1979. Yield losses in barley cultivars caused by spot blotch. Can. J. Plant Pathol. 1: 113-117.

Grewal, T. S., Rossnagel, B. G., Pozniak, C. J. and Scoles, G. J. 2007. Mapping quantitative trait loci associated with barley net blotch resistance. Theor. Appl. Genet. 116: 529-539. Grewal, T. S., Rossnagel, B. G. and Scoles, G. J. 2012. Mapping quantitative trait loci associated with spot blotch and net blotch resistance in a doubled-haploid barley population. Mol. Breed. 30: 267-279.

Karwasra, S. S., Beniwal, M. S. and Singh, R. 1998. Occurrence, cultivar reaction and yield losses due to leaf blight of wheat. Indian Phytopathol. 51: 363-364.
Kuldeep, T., Nandan, R., Kumar, U., Prasad, L. C., Chand, R. and Joshi, A. K. 2008. Inheritance and identification of molecular markers associated with spot blotch (Cochliobolus sativus $\mathrm{L}$.) resistance through microsatellites analysis in barley. Genet. Mol. Biol. 31: 734-742.

Kutcher, H. R., Bailey, K. L., Rossnagel, B. G. and Legge, W. G. 1994. Heritability of common root rot and spot blotch resistance in barley. Can. J. Plant Pathol. 16: 287-294.

Mathre, D. E. 1997. Compendium of barley diseases. American Phytopathological Society, St. Paul, MN. 120 pp.

Nagarajan, S. 1998. DWR leaf blight screening nursery. Progress Report, 1998. CP Vol. V. 44 pp.

Panse, V. G. and Sukhatme, P. V. 2000. Statistical methods for agricultural workers. Indian Council of Agricultural Research, New Delhi, India. pp 68-96.

Singh, J. P. and Singh, V. 1991. Response of hulled and hull less barley to varying levels of nitrogen and phosphorus. Indian J. Agron. 36: 104-107.

Steffenson, B. J., Hayes, P. M. and Kleinhofs, A. 1996. Genetics of seedling and adult plant resistance to net blotch (Pyrenophora teres f. teres) and spot blotch (Cochliobolus sativus) in barley. Theor. Appl. Genet. 92: 552-558.

Valjavec-Gratian, M. and Steffenson, B. J. 1997. Genetics of virulence in Cochliobolus sativus and resistance in barley. Phytopathology 87: 1140-1143.

van Leur, J. G. 1991. Testing barley for resistance to Cochliobolus sativus at ICARDA, Syria. Pages 128-134 in R. D. Tinline, ed. Proceedings of 1st International Workshop on Common Root Rot of Cereals. Saskatoon, SK.

Wilcoxson, R. D., Rasmusson, D. C. and Miles, M. R. 1990. Development of barley resistant to spot blotch and genetics of resistance. Plant Dis. 74: 207-210. 